\title{
Peran Masyarakat Nusantara dalam Konstruksi Kawasan Asia Tenggara sebagai Poros Maritim Dunia pada Periode Pramodern
}

\author{
Singgih Tri Sulistiyono, ${ }^{*}$ Yety Rochwulaningsih, Haryono Rinardi \\ Departemen Sejarah, Fakultas Ilmu Budaya, Universitas Diponegoro \\ Jl. Prof. Soedarto, S.H. Tembalang, Semarang - Indonesia \\ *Alamat korespondensi: singgihtrisulistiyono@live.undip.ac.id \\ DOI: https://doi.org/10.14710/jscl.v5i1.28089
}

Diterima/Received: 18 Januari 2020; Direvisi/Revised: 14 Maret 2020; Disetujui/Accepted: 17 April 2020

\begin{abstract}
The main objective of this article is to trace the pioneering role that might be played by the ancestors of the Indonesian people, Malay-Austronesian, in constructing the Southeast Asian region as a world maritime fulcrum in the pre-modern period. It is very important to be studied considering the fact that until now the historiography of both Indonesia and Southeast Asia still pays little attention to the role of Southeast Asia people in establishing the glory of Southeast Asia as one of the world's maritime axis. That is why their role needs to be elaborated more deeply by exploring broader literatures and historical sources. Likewise, a new perspective also needs to be developed to build a narrative of the role of local communities in the process of globalization in the region. For this purpose, this article will explain how Indonesian ancestors became the decisive pioneers in the reconstruction of the Southeast Asian region as one of the centers of world maritime activity.
\end{abstract}

Keywords: Nusantara; Trade Expansion; Maritime Trade; World Maritime Fulcrum.

\begin{abstract}
Abstrak
Kajian ini bertujuan untuk melacak peran yang mungkin dimainkan oleh leluhur orang Indonesia, Melayu-Austronesia dalam membangun kawasan Asia Tenggara sebagai salah satu tumpuan penting aktivitas kemaritiman pada periode pramodern. Hal ini sangat penting untuk dikaji mengingat adanya fakta bahwa sampai sekarang historiografi Indonesia dan Asia Tenggara masih kurang memperhatikan peran orang-orang Asia Tenggara dalam membangun kejayaan Asia Tenggara sebagai salah satu poros maritim dunia. Itulah sebabnya, peran mereka dijabarkan dengan komprehensif melalui eksplorasi sumber-sumber tradisional dan literatur yang lebih banyak. Demikian juga, perspektif baru perlu dikembangkan untuk membangun narasi mengenai peran komunitas lokal dalam globalisasi di kawasan Asia Tenggara. Untuk hal itu, kajian ini berargumentasi bahwa nenek moyang masyarakat Indonesia merupakan perintis rekonstruksi wilayah Asia Tenggara sebagai salah satu pusat kegiatan maritim dunia.
\end{abstract}

Kata Kunci: Nusantara; Ekspansi Dagang; Perdagangan Maritim; Perdagangan Maritim Dunia.

\section{Pendahuluan}

Artikel ini dimaksudkan untuk menunjukkan bahwa sebelum memasuki zaman modern, Asia Tenggara telah menjadi salah satu kawasan maritim yang paling dinamis di dunia setelah keruntuhan Jalan Sutra darat pada awal milenium pertama. Selain itu, artikel ini juga menunjukkan bahwa kawasan Asia Tenggara telah berkembang menjadi katalis untuk perdagangan internasional antara dua pusat ekonomi dunia, yaitu India dan Cina. Melalui perdagangan maritim internasional, hubungan antara Asia dan Eropa telah meningkat. Hubungan maritim ini telah menempatkan Asia Tenggara sebagai wilayah yang memiliki peran penting dalam proses globalisasi ketika penjelajah Eropa mulai menemukan 'dunia baru' dan berhasil 
mengelilingi bumi untuk pertama kalinya di awal abad ke-15.

Wilayah Asia Tenggara merupakan perpaduan unik dari karakter geografis antara daratan dan pulau-pulau serta laut. Terlepas dari keanekaragaman demografi, kondisi alamiah, dan budayanya, Asia Tenggara telah menjadi wilayah yang mudah dibedakan dari daerah sekitarnya, seperti India, Cina, dan Asia Tengah. Wilayah ini membentang dari delta Yangtze di Cina ke Semenanjung Melayu, termasuk Laut Cina Selatan, Teluk Thailand, dan Laut Jawa. Wilayah ini didominasi oleh budaya thalassocratic dari keturunan rumpun Austronesia (Sulistiyono, dkk., 2018). Oleh karena itu para sejarawan telah menekankan konektivitas maritim di wilayah Asia Tenggara di mana ia dapat dianalisis sebagai satu kesatuan budaya dan ekonomi, seperti yang telah dilakukan dengan cekungan Mediterania. Dalam konteks ini sangat menarik untuk mempelajari sejumlah masalah yang termasuk kekuatan pendorong kemajuan di kawasan Asia Tenggara, yaitu lokasi strategis, modal sosial penduduk, kekayaan alam dan kemampuan untuk menghasilkan berbagai komoditas yang dibutuhkan di internasional.

\section{Kondisi Alamiah}

Wilayah Asia Tenggara merupakan kawasan yang sangat strategis karena terletak di titik pertemuan antara dua benua, Asia dan Australia, dan dua lautan, Samudera Hindia dan Pasifik. Karena faktor ini Asia Tenggara memiliki peran yang sangat penting dalam sejarah hubungan perdagangan maritim antara Cina dan India, sehingga Kawasan ini telah menjadi salah satu wilayah maritim paling maju di dunia sejak awal milenium pertama. Di utara, kawasan ini berbatasan dengan Asia Timur, di barat dengan Asia Selatan dan Teluk Bengal dan timur dengan Samudra Pasifik, di Selatan, juga berbatasan dengan Australia dan Samudra Hindia. Wilayah Asia Tenggara dapat dibagi menjadi dua bagian, yaitu daratan Asia Tenggara dan pulaupulau Asia Tenggara atau maritim. Dari perspektif yang lebih luas, lokasi geografis Asia Tenggara sangat strategis terkait dengan ekonomi, politik, dan budaya (Frank, 1998: 96).

Dari perspektif maritim, Asia Tenggara dikelilingi oleh tiga perairan luas yang sangat penting dalam sejarah dunia, yaitu: Samudra Hindia, Teluk Bengal di barat, dan Laut Cina Selatan di utara, serta Samudra Pasifik di timur. Posisi geografis yang strategis ini telah menempatkan Asia Tenggara sebagai pintu masuk vital dalam hubungan kuno pusat ekonomi, politik dan budaya antara India dan Cina. Selain itu, posisi strategis ini juga didukung oleh tiupan angin muson yang memungkinkan orang-orang yang menghuni wilayah tersebut untuk mengambil bagian penting dari pelayaran dan perdagangan maritim internasional.

Konstruksi geografis Asia Tenggara tidak dapat dilepaskan dari sejarah pembentukan bumi di kawasan ini. Oleh sebab itu kondisi geografis Asia Tenggara saat ini menjadi sesuatu yang telah ditakdirkan oleh proses sejarah yang sangat panjang. Para ahli geologi yakin bahwa bumi ini sebetulnya sudah muncul ratusan juta atau bahkan milyaran tahun yang lalu meskipun pada awalnya masih dalam kondisi yang sangat labil. Keberadaan daratan, laut, gunung, bukit, pantai, dan sebagainya masih dalam keadaan mudah mengalami perubahan. Hal yang sama juga terjadi dengan musim dan cuaca di bumi. Berdasar penelitian para ahli diketahui bahwa sebagian besar lahan kering dunia berada di atas lempeng benua yang pada awalnya masih berupa batu dan bahan mineral lainnya.

Sekitar 330 juta tahun yang lalu, kawasan yang sekarang menjadi wilayah Asia Tenggara merupakan bagian dari lempeng benua selatan yang sangat besar yang oleh para ahli sekarang ini disebut dengan Gondwana. Lempeng ini terdiri dari lempeng Antartika, Australia, India, Afrika, dan Amerika Selatan, dan banyak lagi bagianbagian yang lebih kecil lagi. Dalam perkembangannya lempeng Gondwana dipisahkan dari benua utara yang oleh para ahli disebut sebagai Laurasia oleh Samudera Tethys. Sekitar 200 juta tahun yang lalu, lempeng Gondwana mulai pecah ke dalam beberapa lempeng dan bergerak ke arah utara. Di antara pecahan fragmen tersebut adalah potongan panjang lempeng benua yang oleh para ahli geologi disebut sibumasu karena merupakan cikal-bakal daratan Siam (Thailand), Burma, Malaya, dan Sumatra. Sementara itu, lempeng Burma Barat, bersama dengan fragmen-fragmen yang kemudian menempel ke Sumatra, Kalimantan dan Sulawesi, terpisah dari Gondwana sekitar 135 
juta tahun yang lalu. Sejak sekitar 65 juta tahun yang lalu, sebagian India telah memisahkan diri dari Gondwana dan rantai fragmen lempeng yang terbentang antara Australia dan Asia. Kondisi geologis Indonesia secara mendasar terus mengalami perubahan yang perlahan namun pasti. Hal ini disebabkan oleh gerakan yang menuju ke arah utara dari lempeng Indo-Australia yang pada gilirannya memadatkan pinggiran selatan dan timur kepulauan Indonesia. Sementara itu, bagian timur laut dari kepulauan ini dipengaruhi oleh pergerakan lempeng Pasifik. Gerakan-gerakan ini sangat lambat namun karena berlangsung dalam jangka waktu yang lama sehingga mampu mengubah struktur geologi Indonesia secara mendasar (Cribb, 2000).

Dengan adanya banyak pertemuan di antara lempeng benua dan di antara pecahan lempeng, Kawasan Asia Tenggara khususnya Indonesia menjadi wilayah yang diwarnai dengan ketidakstabilan geologis yang sangat besar. Sebagai akibat dari semacam gerakan dan gesekan di antara fragmen lempeng-lempeng bumi yang tidak terhitung secara pasti jumlahnya, maka sering terjadi getaran-getaran kecil yang tidak bisa diduga. Demikian juga, kawasan ini sering megalami gempa bumi yang bervariasi kekuatannya. Gempa bumi yang besar bisa menyebabkan kerusakan yang luar biasa. Bahkan gempa bumi tektonik dan vulkanik bisa menyebabkan tsunami yang menimbulkan kerugian yang luar biasa.

Uraian di atas menjelaskan bahwa dasar struktur geologis kepulauan Indonesia secara prosesual terbentuk sejak jutaan tahun yang silam. Namun demikian, bentuk dan rupa pulau-pulau yang ada di Nusantara saat ini merupakan hasil dinamika faktor endogen dan eksogen yang relatif baru. Hal ini terkait dengan perubahan yang silih berganti antara zaman glasial dan interglasial pada saat permukaan air laut mengalami perubahan secara silih-berganti terkait dengan perubahan iklim bumi yang masih labil. Ada kalanya pada saat tertentu permukaan laut menjadi turun drastis hingga ratusan meter pada zaman glasial ketika suhu bumi sangat turun dan selanjutnya air laut kembali naik ketika terjadi perubahan iklim ekstrim pada saat suhu bumi meningkat, sehingga menyebabkan lelehnya sebagian es yang ada di kutub. Perubahan permukaan laut global tersebut berlangsung berkali-kali selama jutaan tahun terakhir. Pada masa zaman es terakhir, yang pada puncaknya terjadi sekitar antara 70 ribu tahun lalu hingga sekitar 17.000 tahun yang lalu, permukaan laut turun sekitar 200 meter lebih rendah dari saat ini. Permukaan pulau-pulau yang terletak di kawasan Indonesia bagian barat menjadi tersambung dengan Benua Asia dan membentuk semenanjung atau semacam subbenua Eurasia yang oleh para ahli geologi disebut Dataran Sunda (Sundaland) yang terletak di sebelah tenggara lempeng ini. Sementara itu pada periode yang sama, permukaan Papua dan pulau-pulau yang berdekatan bergabung dengan lempeng Australia bagian utara yang oleh para ahli disebut sebagai Sahulland atau Daratan Sahul. Pada masa itu dataran ini jauh lebih kering jika dibandingkan dengan kondisi sekarang dan menjadi sasaran migrasi manusia sebelum kedatangan gelombang diaspora orang-orang Austronesia. Sementara itu bagian dataran rendah yang pada masa interglasial tertutup air laut berubah menjadi sabana-sabana dan semak-belukar. Selanjutnya terjadi perubahan dramatik lagi terhadap garis pantai sebagai akibat terjadinya zaman interglasial yang berpuncak sekitar 7.500 tahun yang lalu ketika permukaan air laut naik kembali dan membenamkan dataran rendah dataran Sunda dan Sahul sehingga memunculkan rupa bumi Asia Tenggara seperti sekarang ini.

Seperti diketahui bahwa gunung berapi di bumi terbentuk karena keraknya terpecah menjadi lempeng-lempeng tektonik. Lempeng-lempeng tektonik ini bersifat kaku dan mengambang di atas lapisan mantel bumi yang lebih panas dan lunak. Dalam hubungan inilah maka gunung berapi di bumi sering ditemukan di batas divergen dan konvergen dari lempeng tektonik tersebut. Divergen merupakan pergerakan lempeng; di mana lempeng-lempeng bergerak saling menjauh satu dengan yang lain. Divergen ini menyebabkan magma dari pusat bumi yang akan naik membentuk lantai samudera atau kerak samudera. Contohnya adalah MOR (Mid Ocean Ridges) di dasar samudera Atlantik. Pergerakan lempeng di mana lempeng-lempeng bergerak saling mendekati satu dengan yang lain, gaya yang bekerja pada gerak ini adalah gaya kompresional disebut sebagai gaya konvergen. 
Lokasi gunung berapi yang paling dikenali adalah gunung berapi yang berada di sepanjang busur Cincin Api Pasifik (Pacific Ring of Fire). Busur Cincin Api Pasifik merupakan garis pergesekan antara tiga lempengan tektonik. Indonesia berada di jalur gempa teraktif di dunia karena dikelilingi oleh Cincin Api Pasifik dan berada di atas tiga tumbukan lempeng benua, yakni, Indo-Australia dari sebelah selatan, Eurasia dari utara, dan Pasifik dari timur. Kondisi geografis ini di satu sisi menjadikan kawasan Asia Tenggara sebagai wilayah yang rawan bencana letusan gunung api, gempa, dan tsunami, namun di sisi lain menjadikan Indonesia sebagai wilayah subur dan kaya secara hayati serta bahan-bahan mineral. Debu akibat letusan gunung berapi menyuburkan tanah, sehingga masyarakat tetap banyak yang tinggal di area sekitar gunung berapi. Kawasan ini menjadi penghasil berbagai jenis komoditas pertanian dan perkebunan yang sangat dibutuhkan untuk bahan industri. Kekayaan ini yang juga menyebabkan kawasan Asia Tenggara selalu terlibat aktif dalam perekonomian global semenjak zaman kuno.

Oleh karena luasnya wilayah Indonesia, tidak semua tanah di kepulauan Indonesia subur. Pulau Jawa bagian tengah dan timur, Bali, dan sebagian Sumatra bagian timur laut di mana aktivitas vulkanik yang belum selesai telah meninggalkan warisan yang kaya dalam bentuk lapisan tanah yang tebal dan subur. Abu vulkanik di wilayah ini telah menyediakan kondisi ideal untuk pertanian intensif. Tanah vulkanik di Jawa Barat, sebagian besar Sumatra, Sulawesi dan Maluku, di sisi lain, lebih asam dan kurang menguntungkan untuk pertanian, namun masih cocok untuk perkebunan. Kemajuan teknologi pemupukan akhirnya bisa mengatasi tanah yang asam, sehingga cocok baik untuk pertanian maupun perkebunan. Di beberapa daerah di Nusantara memang merupakan daerah tandus, namun merupakan daerah yang memiliki kelebihan tersendiri; misalnya daerah Nusa Tenggara Timur, meskipun merupakan daerah kering, namun merupakan daerah penghasil peternakan dan kayu cendana (Hall, 2011).

Dinamika angin merupakan faktor penting yang menentukan iklim dan dinamika kehidupan di Indonesia. Hal ini terkait erat dengan posisi silang Indonesia di antara dua benua dan dua samudera yang berpengaruh berupa angin musim timur dan barat atau dikenal juga dengan istilah muson Asia Tenggara dan muson Australia. Untuk Indonesia, Muson Asia Tenggara dan Australia masingmasing membawa pengaruh berupa musim, yaitu musim hujan dan musim kemarau. Angin muson atau angin musim merupakan angin yang secara tahunan berubah arah. Oleh karena itu, di samping digunakan untuk patokan para petani dalam menanam berbagai produk pertanian dan perkebunan, angin musim juga dimanfaatkan oleh para pelaut untuk melakukan kegiatan pelayaran dan perdagangan serta untuk kepentingan migrasi (Sulistiyono, 2015).

Sistem angin muson sangat menentukan pelayaran dan perdagangan antarpulau di kawasan Asia Tenggara serta antara kawasan ini dengan dunia luar. Aktivitas pelayaran dan perdagangan secara reguler diuntungkan dari perubahan periodik yang disebabkan oleh angin muson ini. Selama musim kemarau yang berlangsung mulai sekitar April hingga Oktober, angin muson bergerak dari timur dan tenggara menuju ke barat dengan kecepatan tertinggi pada Agustus. Musim hujan berlangsung dari Desember hingga April. Angin muson barat menjadi lemah ketika mereka tiba di bagian timur kepulauan Indonesia. Implikasinya adalah bahwa daerah-daerah ini memiliki lebih sedikit curah hujan daripada daerahdaerah di bagian barat Kepulauan Indonesia. Di bagian timur Nusantara, musim kemarau juga lebih panjang daripada di bagian barat. Di wilayah sekitar Laut Jawa dan sebelah baratnya, angin barat menyebabkan hujan lebat, sementara pada muson timur cuaca berkabut.

April adalah bulan transisi. Di bagian barat Kepulauan Indonesia, transisi arah angin muson dimulai pada April meskipun muson barat masih dominan. Pada November, angin muson barat meningkat dan mencapai kecepatan tertinggi pada Januari dan Februari. Namun pada Maret, angin muson ini menjadi lemah. Akan tetapi, hal ini cukup variatif karena bergantung kepada topografi lokal. Di perairan sekitar Jakarta misalnya, pengaruh angin darat dan angin laut dapat mencapai bagian utara Kepulauan Seribu. Selama muson timur, langit sedikit berawan dan akan berkabut saat fajar, tetapi setelah beberapa jam terbitnya matahari, kabut menjadi awan. Selama musim angin barat, terutama pada bulan Januari 
dan Februari, hujan lebat biasanya turun di malam hari. Meski demikian, selama musim kemarau langit bisa sangat jernih meski kadang-kadang masih mendung (Stibbe \& Sandbergen, 2018).

Di kawasan timur kepulauan Indonesia, muson timur lebih dominan dan lebih panjang daripada muson barat. Pada April, muson timur yang mendominasi kawasan ini pada awal tahun bertiup dengan cepat dan terus-menerus dari Mei hingga Oktober. Sementara itu November merupakan masa transisi dari muson barat menuju ke muson timur. Karakter terkuat selama masa transisi ini adalah bahwa angin bertiup tidak beraturan dan datang dari segala arah. Hal ini mempengaruhi angin darat dan angin laut juga. Selama muson timur, langit biasanya berkabut di malam hari. Setelah matahari bersinar langit akan cerah dan jernih. Namun demikian, kadangkadang angin yang menuju ke arah barat laut membawa debu, sehingga membatasi jarak pandang para pelaut (Ministerie van Marine, 1903).

Di bagian selatan Asia Tenggara atau di tengah kepulauan Indonesia, khususnya di kawasan Laut Jawa, transisi dari musim hujan (muson barat) ke musim kemarau (muson timur) dimulai lebih awal yaitu sekitar pada Maret dan April. Selama masa transisi (pancaroba) ini arah angin sering berubah-ubah. Dari Mei hingga Oktober muson timur bergerak secara konsisten ke barat dan barat laut dan mencapai kecepatan tertinggi pada bulan Agustus. Pada Oktober, arah angin mulai berubah hingga November. Pada Desember, angin barat mulai bergerak ke arah yang konstan dan mencapai kecepatan tertinggi pada Januari dan Februari. Selama muson barat, curah hujan di Laut Jawa lebih berat daripada di daratan Jawa, sedangkan pada periode muson timur hujan (seandainya terjadi) lebih banyak di daratan. Air pasang biasanya terjadi pada bulan purnama, tetapi hampir tidak pernah mencapai dua meter. Di sepanjang pantai selatan Kalimantan, air pasang menurun seiring dengan perjalanan ke timur sampai tiba di muara Sungai Jelahi. Di bagian barat Laut Jawa, air pasang bisa mencapai antara satu hingga satu setengah meter dan di bagian timur bisa mencapai sekitar tiga meter (Ministerie van Marine, 1903; Stibbe and Sandbergen, 1918).
Angin muson bertiup dengan tenang di sepanjang Selat Malaka. Dataran tinggi Sumatra dan Semenanjung Malaya menghalangi laju baik muson timur maupun barat. Pedagang biasanya mendapat manfaat dari muson barat laut dengan pelayaran dari Melaka ke Riau, Johor dan pantai utara Jawa untuk selanjutnya menuju Makassar dan ke kepulauan Maluku. Mereka menggunakan rute dari Malaka ke Kepulauan Maluku di sepanjang pantai timur Sumatra, pantai utara Jawa (Banten, Jakarta, Cirebon, Cirebon, Gresik, dan lain-lain) kemudian ke Bali, Lombok, Sumbawa, Makassar dan pulau-pulau di Maluku. Namun demikian, mereka juga bisa menggunakan jalur perdagangan melalui pantai selatan Kalimantan untuk mencapai Makassar. Pelayaran dari Makassar ke pulau-pulau Maluku mengambil satu dari dua rute. Rute pertama dimungkinkan selama musim barat laut Oktober-Desember. Kapal mampu berlayar ke selatan menuju Pulau Buton dan kemudian berbelok ke kiri untuk mencapai Banda dan Ambon. Rute kedua digunakan selama musim tenggara dari Juni sampai Agustus untuk perjalanan dari Makassar ke Maluku Utara, kemudian ke Papua melalui Menado di Sulawesi Utara, Ternate dan Seram. Pada rute ini, kapal juga menggunakan angin darat dan angin laut dari daratan utama Sulawesi, yang bertiup selama JuliSeptember. Pada pelayaran pulang ke arah barat dari Papua dan pulau-pulau Maluku, kapal umumnya mendapat manfaat dari muson timur laut yang berlangsung antara Mei-September. Namun demikian, perjalanan ini mengharuskan singgah di beberapa pelabuhan, karena angin menjadi lebih lemah ketika melintasi Flores dan Laut Jawa pada Juni di bawah pengaruh muson tenggara bulan Juni-Agustus. Kapal-kapal bisa melanjutkan perjalanan ke arah barat selama musim timur laut yang berlangsung pada Agustus ketika arus bergerak ke arah yang sama dengan arah angin. Para pelaut sangat menyadari betapa sulitnya berlayar melawan angin dan sekaligus arus laut (Poelinggomang, 1991).

Di perbatasan barat daya Laut Jawa (di sekitar Selat Bangka), terdapat ombak yang kuat tetapi tidak teratur, dan sangat dipengaruhi oleh angin muson. Air pasang dari Laut Jawa memasuki Selat Bangka dan bertemu dengan air pasang lainnya yang datang dari Laut Cina Selatan. Arah 
arus air laut sepenuhnya dipengaruhi oleh angin yang bertiup di selat. Selama muson barat, kapal berlayar dari Lampung dan Palembang ke Pontianak dan kemudian ke pantai selatan Kalimantan. Kapal-kapal itu berlayar pulang selama musim timur laut (dari Mei hingga September). Untuk berlayar ke Jakarta, kapal dapat menggunakan muson utara selama Januari-April. Selain itu, selama musim tenggara pada JuniAgustus mereka dapat berlayar ke pelabuhan di sepanjang pantai timur Sumatra, bahkan ke Singapura, Malaka, dan Penang (Findlay, 1898).

Sementara itu, kapal-kapal yang berlayar di sepanjang pantai utara Jawa sangat dipengaruhi oleh angin darat dan laut. Selama musim timur, kapal yang melakukan perjalanan dari Batavia ke Surabaya harus memanfaatkan angin darat dan laut serta harus berlayar tidak terlalu jauh dari pantai. Jika kapal berlayar dari Jakarta pada petang atau malam hari bisa memanfaatkan angin darat hingga mencapai daerah Terumbu Cirebon. Dalam pelayaran kapal harus menjaga setidaknya $10 \mathrm{mil}$ dari pantai untuk menghindari Batuan Pemalang dan Korowelang serta Karang Bapang sampai mendekati Semarang. Setelah melewati Semarang, kapal dapat menggunakan angin laut untuk mencapai Surabaya (Knaap, 1996). Selama muson barat laut, ketika sebuah kapal telah melewati pulau-pulau Mandalika, disarankan untuk tidak berlayar terlalu dekat dengan wilayah itu, karena arus timur akan membawa kapal dengan cepat melewati Selat Surabaya. Jika hal itu terjadi maka sebuah kapal layar yang berusaha mencapai Selat Surabaya dapat menghadapi bahaya besar, karena harus menghadapi angin barat dan arus yang berlawanan (Findlay, 1898).

Angin muson barat laut dan timur laut tidak begitu kuat dan tidak teratur terhalangi oleh Pulau Borneo. Hal ini membuat pelayaran di perairan Laut Jawa bagian utara lebih aman dan bebas dari badai. Pengaruh angin laut dan darat, baik yang berasal dari Sulawesi atau dari Pulau Kalimantan juga dominan di sini. Angin darat dari Sulawesi bertiup selama musim tenggara pada JuliSeptember dan angin laut bergerak selama musim angin barat laut Oktober - April. Sementara itu, angin sepoi-sepoi dari Kalimantan berhembus selama muson barat laut dan angin laut di musim tenggara. Hal ini memungkinkan terjadinya hubungan perdagangan antara Makassar dan pelabuhan di sepanjang Pantai Barat Sulawesi, seperti Parepare, Suppa, Majene, dan Kaili dengan pusat perdagangan di sepanjang pantai tenggara Kalimantan seperti Banjarmasin, Samarinda, dan Bulungan. Di pantai selatan Kalimantan, angin muson tenggara bertiup dari Mei hingga September, disertai dengan hujan deras. Selama musim angin barat laut (dari Oktober hingga April) hujan terus-menerus dan badai kadang terjadi. Di perairan ini, arus air laut pada umumnya mengikuti arah angin (Findlay, 1898).

Pengaruh muson tenggara dan utara juga memungkinkan hubungan pelayaran antara wilayah Laut Jawa dan negara-negara yang terletak di utara kepulauan Indonesia seperti Filipina, Jepang, dan Cina. Pelaut dari Tiongkok, Sulu, dan Luzon tiba di Makassar dengan menggunakan angin utara. Bahkan sebelum kehadiran orang Barat, rute pelayaran antara Cina dan kepulauan Indonesia telah berkembang. Rute ini meliputi Cina-Jawa-Kepulauan Sunda Kecil dan pulaupulau Maluku. Dengan menggunakan muson utara, mereka juga berlayar di sepanjang Pantai Barat Kalimantan. Muson ini juga digunakan oleh orang Makassar untuk menyeberangi Laut Flores ke kawasan Nusatenggara. Mereka bahkan mampu mencapai pantai utara Australia. Pelayaran pulang dilakukan selama angin muson tenggara (Poelinggomang, 1991; Hall, 1985; Cense, 1952).

Dari penjelasan di atas terlihat dengan jelas adanya faktor alamiah yang terkait dengan aspek geografis, klimatologis, dan topografis yang mengondisikan masyarakat kepulauan Indonesia sebagai masyarakat maritim. Siklus angin muson di perairan kepulauan Indonesia memfasilitasi pelayaran dan perdagangan antarwilayah di kepulauan Indonesia dan kawasan di sekitarnya bahkan pelayaran dan perdagangan internasional. Dengan demikian, keragaman potensi daerahdaerah yang berbeda-beda dengan difasilitasi oleh sistem angin muson telah mendorong perdagangan antardaerah dan internasional di kawasan Nusantara (Anstey, 1929).

Sejak sebelum abad Masehi, Asia Tenggara telah dikenal luas sebagai wilayah yang sangat makmur. Oleh karena sumber informasi tertulis setempat yang terbatas, sebagian besar informasi mengenai Kawasan ini berasal dari luar. Mereka menyebut daerah ini sebagai 'Golden Chersonese' atau negeri emas. Kenyataannya sebagian wilayah 
ini sejak zaman dulu merupakan penghasil emas. Selain itu, wilayah ini juga menghasilkan rempahrempah, terutama lada, dan beberapa produk kehutanan seperti kayu aromatik dan damar serta produk lainnya (Wheatley, 1961). Produk-produk ini dibutuhkan oleh dua negara raksasa pada waktu itu, yaitu China dan India, dan negara-negara yang terletak di sebelah baratnya.

Informasi tentang tempat yang disebut 'negeri emas' itu ditulis oleh ahli geografi Romawi yang bernama Ptolomeus pada pertengahan abad kedua Masehi yang mengacu kepada Semenanjung Melayu dan wilayah Sumatra (Hall, 2011). Tidak berlebihan bahwa pengetahuan geografis Romawi dikenal luas oleh para pedagang dari India karena ada hubungan erat antara India dan Yunani melalui agresi Alexander the Great pada abad ke-4 SM (Ray, 2003). Mereka memperoleh informasi itu kemungkinan besar berasal dari para pelaut Nusantara yang telah menjelajah hingga Madagaskar dan pantai timur Afrika yang juga merupakan patner dagang Romawi. Selain dari emas, pulau-pulau di Asia Tenggara menghasilkan produk pertanian, kehutanan, dan perkebunan yang sangat dibutuhkan oleh perdagangan internasional.

\section{Peran Masyarakat Nusantara}

Para arkeolog menunjukkan bahwa jaringan perdagangan maritim awal di Samudera Hindia dibangun oleh orang-orang Austronesia di Benua Asia Tenggara yang telah mampu membangun kapal-kapal pengangkut samudera pertama. Mereka memelopori rute perdagangan maritim dari Asia Tenggara dengan India Selatan dan Sri Lanka paling awal 1500 SM. Mereka melakukan pertukaran budaya material seperti perahu cadik, dan komoditas seperti kelapa, cendana, pisang, dan tebu; serta menghubungkan budaya material India dan Cina. Orang Indonesia umumnya melakukan bisnis perdagangan rempah-rempah dengan Afrika Timur menggunakan perahu cadik dan berlayar dengan bantuan angin muson di Samudera Hindia. Jaringan perdagangan ini mencapai Afrika dan Semenanjung Arab, menghasilkan kolonisasi Austronesia di Madagaskar pada paruh pertama milenium pertama Masehi. Masuk akal untuk menduga bahwa orang India, Yunani, dan Romawi tahu bahwa negeri emas di timur berasal dari orang Melayu Austronesia yang berlayar dan berdagang di berbagai wilayah pengaruh mereka (Manguin, 1979).

Pedagang Melayu Austronesia memperluas perdagangan maritim mereka ke pantai timur Afrika. Salah satu produk pertama yang mereka perdagangkan adalah kayu manis yang diproduksi di wilayah Vijaya (Bind Dinh) dan emas yang ditambang di wilayah Amarawat di Vietnam serta di wilayah Jambi di Pulau Sumatra (Hall, 2011). Produk-produk ini dibutuhkan di India dan negaranegara di barat. Bahkan oleh pedagang India, kayu manis diekspor kembali bersama dengan lada Malabar, ke Mesopotamia dan Mediterania. Dari hubungan dagang antara pedagang India dan pedagang Austronesia-Melayu, berbagai informasi tentang kekayaan wilayah timur diketahui oleh orang India dan kemudian juga orang-orang Mediterania. Ini menunjukkan bahwa pelaut Asia Tenggara memiliki peran penting dalam pengembangan perdagangan maritim Asia Tenggara.

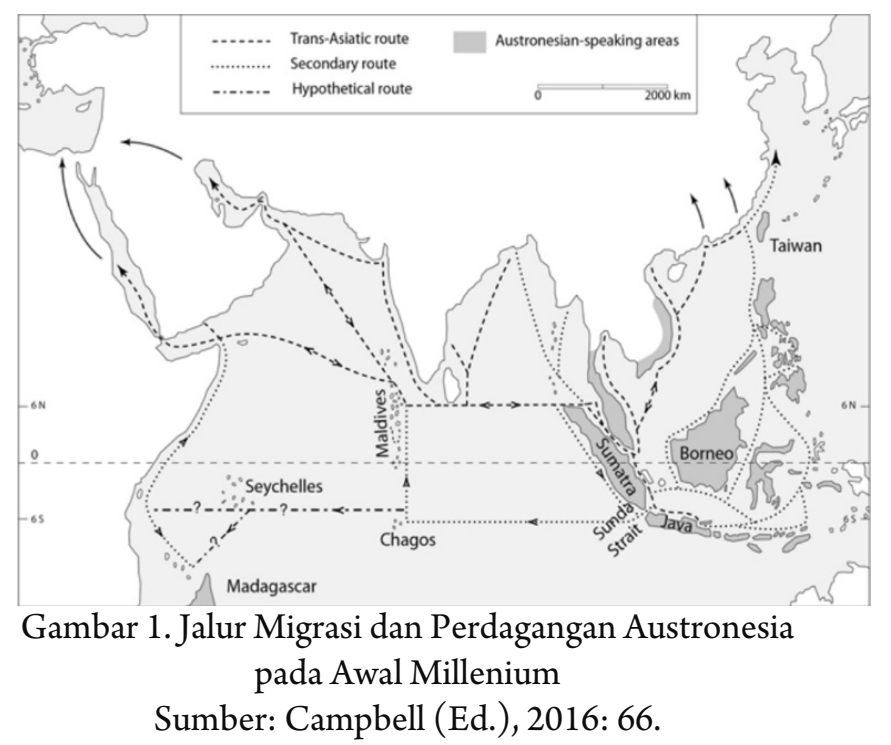

Berdasar pada penelitian Coedes dapat dilihat bahwa salah satu faktor yang mendorong ekspansi pelaut India ke Asia Tenggara terkait dengan hilangnya sumber daya emas India yang berasal dari Siberia yang dibawa melalui Jalan Sutra. Terutama ketika Kaisar Vespasianus Roma (69-79 M) memberlakukan larangan ekspor besarbesaran terhadap koin emas ke luar negeri, India semakin kekurangan emas. Dengan demikian pelaut India terdorong untuk mencari sumber 
emas dari timur yang menurut informasi yang tersebar sangat kaya akan emas. Informasi yang diketahui dari pelaut Melayu Austronesia yang tinggal di Nusantara telah menciptakan fantasi 'negeri emas' di Asia Tenggara (Coedes, 1975; Tripati, 2017). Temuan Coedes sebagian besar diikuti oleh lebih banyak sejarawan junior seperti Hall (1955), Wheatley (1983), Ray (1994), Sen (2003), dan Chauduri (1985). Berdasar pada informasi ini para pedagang India kemudian mencoba mencari emas ke timur. Memang kemudian terbukti bahwa pulau Sumatera (terutama wilayah Jambi yang merupakan pusat kerajaan Melayu) merupakan penghasil emas. Emas juga ditemukan di wilayah selatan Vietnam. Selain emas, Asia Tenggara, baik benua dan pulau, juga menghasilkan produk tropis lainnya yang juga diperdagangkan dalam perdagangan maritim internasional, seperti madu, cendana, kapur barus, cengkeh, lada, pala, minyak penyu, minyak penyu, kulit rusa, dan yang lain (Gupta, 1987). Demikian juga kayu manis juga ditemukan di wilayah pesisir Laut Cina Selatan (Hall, 2011).

Butuh waktu yang cukup lama karena baru abad kedua Masehi, hubungan perdagangan maritim antara Asia Tenggara mulai dibangun secara intensif. Bukti tertulis tentang pengaruh budaya India baru terlihat sejak abad ke-5 M, yaitu meningkatnya pengaruh Hindu dan Buddha di Asia Tenggara (Coedes, 1975). Ini bisa dilihat dari kemunculan beberapa kerajaan yang menunjukkan pengaruh luar (terutama India), seperti Kerajaan Funan di Vietnam saat ini, Kutai di Kalimantan Timur, Taruma di Jawa Barat, dan Kantholi di Sumatra (Hall, 2011). Ini menunjukkan bahwa aktivitas perdagangan maritim memiliki banyak pengaruh di bidang sosial, budaya, politik, dan kepercayaan di wilayah tersebut.

Berdasar pada bukti sejarah, kepeloporan orang-orang Cina dalam membangun hubungan perdagangan maritim dengan Asia Tenggara tertinggal jauh di belakang India. Istana Cina mencatat lebih banyak informasi bahwa pelaut dari Asia Tenggara datang ke Cina. Mereka adalah pelaut Melayu-Austronesia (Kunlun atau Nusantara) yang membawa kapal-kapal khas Melayu (Kunlunpo) yang menarik perhatian orang Cina (Hall, 2011; Wolters, 1967). Perhatian Cina terhadap Asia Tenggara yang juga dikenal sebagai (Nan Yang) agak lambat (Bentley, 1993). Selama berabad-abad Cina lebih tertarik mengembangkan perdagangannya dengan wilayah yang terletak di barat (Asia Tengah, Asia Barat, dan Eropa) melalui jalur darat, yang dikenal sebagai Jalur Sutra. Perhatian Cina terhadap perdagangan maritim di Asia Tenggara masih kurang. Mereka memiliki hubungan dengan Asia Tenggara (terutama dengan Funan) hanya ketika itu terkait dengan perdagangan Asia Barat dan untuk mengamankan wilayah di bawah kendalinya yaitu Vietnam (Wolters, 1967). Jadi pengetahuan Cina tentang "Dunia Selatan" atau dunia laut selatan kurang dibandingkan dengan "Dunia Barat". Hanya setelah abad ke-5 barulah mereka memiliki sedikit pengalaman di Asia Tenggara (Groeneveldt, 1960). Kapal-kapal Tiongkok berlayar ke Asia Tenggara secara teratur sejak abad ke-11. Tampaknya orang-orang Asia Tenggara yang pertama kali memprakarsai dan menghubungkan perdagangan maritim antara India dan Cina.

Awalnya, kapal-kapal India menurunkan kargo di pantai barat Semenanjung Melayu dan kemudian mengangkut kargo melalui Tanah Genting Kra ke Teluk Siam. Setelah itu, kargo dikirim ke pelabuhan di pantai Cina Selatan dengan mengikuti garis pantai di sisi Delta Mekong dan kemudian berhenti di pelabuhan Funan. Dari sini, kapal berlayar ke pelabuhan Linyi dan kemudian pergi ke Delta Sungai Merah di Vietnam Utara yang dikontrol oleh Cina dari awal abad ke abad ke-10 (Hall, 2011). Selain posisinya yang strategis, dengan sumber daya alam yang berlimpah dan produktif, Wade (2009) juga mencatat bahwa keruntuhan Jalur Sutra terkait dengan perubahan kebijakan perdagangan luar negeri Tiongkok selama era dinasti Song sejak abad ke-10. Orang Cina mulai mengambil keuntungan dari jaringan perdagangan maritim India-Cina yang telah dirintis oleh orang Asia Tenggara.

Kepioniran masyarakat Nusantara dalam membangun konektivitas perdagangan maritim antara India dan Cina dapat dilihat dari penelitian kapal karam di Laut Cina Selatan sebagaimana yang dikaji oleh Michael Fleckers. Sepanjang milenium pertama, hanya ada enam kapal karam yang ditemukan di Laut Cina Selatan dan sebagain besar merupakan kapal-kapal Nusantara. Sebagian kecil merupakan kapal-kapal Arab atau pun Persia. Ini menunjukkan bahwa pelayaran tertua ke Cina dilakukan sebagian besar oleh orang-orang 
Nusantara. Bahkan situs kapal tertua yang ditemukan di Laut Cina selatan dari abad ke-4 merupakan kapal Nusantara. Tidak ditemukan situs kapal karam lain. Situs kapal karam Cina baru ditemukan untuk abad ke-12 dan itu menunjukkan bahwa kedatangan kapal-kapal Cina ke Asia Tenggara agak terlambat ketika orang-orang Nusantara dan India sudah jauh menjelajah ke Cina (Fleckers, 2017).

Kedatangan banyak kapal Asia Tenggara dan Arab semakin mendorong perkembangan perdagangan maritim antara Asia Tenggara dan Cina. Terlebih lagi, Cina adalah wilayah produktif dan memiliki populasi besar sebagai pasar potensial untuk produk-produk Asia Tenggara. Perdagangan dengan China mengalami kemunduran setelah keruntuhan Dinasti Song karena perang dan kelaparan. Namun, selama Dinasti Yuan dan kemudian Dinasti Ming dari abad ke-13 hingga 16 kondisi ini dapat dipulihkan. Ekspedisi Zheng $\mathrm{He}$ antara 1405 dan 1431 juga memainkan peran penting dalam meningkatkan perdagangan maritim antara Asia Tenggara dan Cina.

Perkembangan kekuatan Islam di Barat juga telah menjadi faktor penting yang telah mendorong perkembangan perdagangan maritim di Asia Tenggara (Wade, 2009). Perluasan kekuatan Khalifah Umayyah dan Abbasiyah dan periode-periode berikutnya telah mendorong ekspansi jaringan perdagangan maritim Asia Tenggara. Permintaan berbagai komoditas yang dikirim oleh wilayah Asia Tenggara tidak hanya terbatas pada pusat-pusat ekonomi dan peradaban Islam, tetapi juga menjangkau seluruh Eropa melalui perluasan kekuatan Islam di Asia Barat dan Afrika Utara serta Eropa Barat. Demikian juga peran pedagang dan pelaut Islam semakin penting untuk menggantikan peran pedagang Hindu / Buddha. Puncak perkembangan ini terjadi pada akhir abad ke-15 hingga abad ke-17 ketika akhirnya armada Eropa berhasil mendominasi simpulsimpul penting perdagangan maritim Asia Tenggara.

\section{Simpulan}

Uraian di atas menjelaskan bahwa masyarakat Nusantara memiliki peran pionir dalam membangun wilayah Asia Tenggara sebagai poros maritim dunia pada periode pra-modern. Studi ini sangat penting untuk ditindaklanjuti guna memperkaya historiograsi Indonesia dan Asia Tenggara yang masih mengesampingkan peran masyarakat losal dalam proses globalisasi ekonomi melalui kegiatan pelayaran dan perdagangan maritim internasional. Dalam mengeksplorasi peran mereka dalam elayaran dan perdagangan internasional di kawasan Asia Tenggara perlu didukung oleh lebih banyak sumber penelitian dari lokal di kepulauan Indonesia, Asia Tenggara, India, dan Cina. Perspektif baru juga perlu dikembangkan dalam rangka untuk membangun narasi yang memberikan peran penting komunitas lokal dalam konstruksi konektivitas maritim antara India dan Cina serta kawasan yang lebih luas lagi.

\section{Referensi}

Anstey, A. (1929). The Trade of the Indian Ocean. London, New York, Toronto: Longman Green \& Co.

Bentley, J. H., (1993). Old World Encounters: Cross-Cultural Contacts and Exchanges in Pre-Modern Times. Oxford University Press, New York.

Campbell, G. (ed.). (2016). Early Exchange between Africa and the Wider Indian Ocean World. Montreal: Palgrave, Macmillan.

Cense, A. A. "Makassarsche-Boeginese Pruwvaart op Noord-Australië." Bijdragen tot de Taal-, Land -en Volkenkunde, 108: 248-265.

Coedes, G. (1975). The Indianized State of Southeast Asia, translated. ed. ANU Press, Canberra.

Cribb, R. (2000). Historical Atlas of Indonesia. Honolulu: University of Hawaii Press.

Findlay, A. G. (1889). A directory for the navigation of the Indian Archipelago and the coast of China from the Straits of Malacca and Sunda, and the passage east of Java to Canton, Shanghai, The Yellow Sea, and Korea. London: Laurie.

Flecker, M. Krahl, R. Guy, J. (2017). The Tang

Shipwreck: Art and Exchange in the 9th

Century. Singapore: Asian Civilisations

Museum. 
Frank, A. G. (1998). ReOrient: Global Economy in the Asian Age. Los Angeles \& London: University of California Press.

Groeneveldt, W. P. (1960). Historical Notes on Indonesia \& Malaya Compiled from Chinese Sources. Bhatara, Jakarta.

Gupta, A. D. (1987). "The Maritime Trade of Indonesia, 1500-1800," in Gupta, A. D., Pearson, M. N. (eds.), India and the Indian Ocean, 1500-1800. London \& Calcuta: Oxford University Press.

Hall, D. G. E. (1955). History of South-East Asia. St Martin's Press, New York.

Hall, K. R. (1985). "The Opening of the Malay World to European Trade in the Sixteenth Centuries." Journal of the Malayan Branch of the Royal Asiatic Society, Vol. 58 (2): 89.

Hall, K. R. (1985). Maritime Trade and State Development in Early Southeast Asia. Honolulu: University of Hawaii Press.

Hall, K. R. A. (2011). History of Early Southeast Asia: Maritime Trade and Societal Development, 100-1500. Rowman \& Littlefield, Plymouth.

Knaap, G. J. (1996). Shallow Waters, Rising Tide: Shipping and Trade in Java around 1775. Leiden: KITLV Press.

Manguin, Pierre-Yves M. (1979). "Austronesian Shipping in the Indian Ocean: From Outrigger Boats to Trading Ships," in Campbell, G. Early Exchange Between Africa And The Wider Indian Ocean World. Macmillan: Palgrave.

Ministerie van Marine (1903). Zeemansgids voor den Oost Indischen Archipel. The Hague: Mouton.

Poelinggomang, E. L. (1991). Proteksi dan Perdagangan Bebas: Kajian tentang Perdagangan Makassar pada Abad ke-19. Vrije Universiteit Amsterdam.

Ray, H. P. (1994). Winds of Change: Buddhism and the Maritime Links of Early South Asia. Delhi, New York: Oxford University Press.

Ray, H. P. (2003). The Archaeology of Seafaring in Ancient South Asia. Cambridge. Cambridge University Press, Cambridge.

Sen, T. (2003). Buddhism, Diplomacy and Trade: The Realignment of Sino-Indian Relations, 600-1400. Honolulu: University of Hawaii Press.
Sen, T. (2003). Buddhism, Diplomacy and Trade: The Realignment of Sino-Indian Relations, 600-1400. Honolulu: University of Hawaii Press.

Stibbe, D. G., Sandbergen, F. J. W. H. (1919). Encyclopaedie van Nederlandsch-Indië, deel II. Leiden: Nijhoff.

Sulistiyono, S. T. (2015). Diaspora Maritim dan Formasi Keindonesiaan. Jakarta: Badan Informasi Geospasial.

Sulistiyono, S. T. Masruroh, N. N., Rochwulaningsih, Y. (2018). "Contest For Seascape: Local Thalassocracies and SinoIndian Trade Expansion in the Maritime Southeast Asia During the Early Premodern Period." Journal of Marine and Island Cultures, Vol. 7 (2).

Tripati, S. (2017). "Seafaring Archaeology of the East Coast of India and Southeast Asia during the Early Historical Period." Anc. Asia, 8. https://doi.org/10.5334/aa.118

Wade, G. (2009). An Early Age of Commerce in Southeast Asia, 900-1300 CE. Journal of Southeast Asian Studies, Vol. 40 (2):s 221. https://doi.org/10.1017/S0022463409000 149.

Wheatley, P. (1961). The Golden Khersonese, Studies in the Historical Geography of the Malay Peninsula before $A D$ 1500. Kuala Lumpur: Malaysian Branch of the Royal Asiatic Society.

Wheatley, P. (1983). Nagara and Commandery: Origins of the Southeast Asian Urban Traditions. Chicago: Chicago University Press.

Wolters, O. W. (1967). Early Indonesia Commerce: A Study of the Origins of Srivijaya. New York: Cornell University Press. 